Summer 2013

\title{
Transnational Normative Orders: The Constitutionalism of Intra- and Trans-Normative Law
}

Poul F. Kjaer

Copenhagen Business School, pfkj.dbp@cbs.dk

Follow this and additional works at: https://www.repository.law.indiana.edu/ijgls

Part of the Constitutional Law Commons, and the International Law Commons

\section{Recommended Citation}

Kjaer, Poul F. (2013) "Transnational Normative Orders: The Constitutionalism of Intra- and TransNormative Law," Indiana Journal of Global Legal Studies: Vol. 20 : Iss. 2 , Article 9.

Available at: https://www.repository.law.indiana.edu/ijgls/vol20/iss2/9

This Symposium is brought to you for free and open access by the Law School Journals at Digital Repository @ Maurer Law. It has been accepted for inclusion in Indiana Journal of Global Legal Studies by an authorized editor of Digital Repository @ Maurer Law. For more information, please contact rvaughan@indiana.edu.

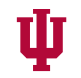

JEROME HALL LAW LIBRARY INDIANA UNIVERSITY Maurer School of Law
Bloomineton 


\title{
Transnational Normative Orders: The Constitutionalism of Intra- and Trans-Normative Law
}

\author{
POUL F. KJAER ${ }^{*}$
}

\begin{abstract}
No weakening, but rather an expansion, of statehood can be observed in the contemporary world. This does not, on the other hand, imply that extensive forms of constitutional ordering do not exist outside the realm of states. Instead, the evolution of world society has been characterized by a protracted dual movement where the expansion and densification of statehood and autonomous forms of transnational ordering gradually emerged in a mutually constitutive fashion. One implication of this is that neither the concept of the state nor the concept of nonstate transnational entities is adequately capable of delineating the object of constitutional analysis. Instead, the concept of normative orders has been introduced as an overarching category capable of identifying the contexts within which constitutional ordering emerges.

Subsequently, a distinction between the internal and external dimensions of the law of normative orders has been introduced, specifying them as respectively oriented towards establishing internal condensation of a given normative order and external compatibility between different normative orders. With this background, a framework for the analysis of constitutional frameworks of normative orders developed. The central element is a distinction among three dimensions: First, a constitution implies a coupling between a constitutional object, in the form of a hierarchical organization of a given normative order capable of reproducing an autonomous source of authority, and a concordant legal framework. Second, constitutionalization implies a coupling between an internal reconstruction of an external constitutional subject within the constitutional object, and the register of legal rights,

* Department of Business and Politics, Copenhagen Business School. I would like to thank the organizers and participants, especially Anna Beckers and Gunther Teubner, of the conference Societal Constitutionalism and Globalization, Torino, May 17-19, 2012, for extremely useful and inspiring comments on an earlier version of this article.
\end{abstract}

Indiana Journal of Global Legal Studies Vol. 20, Issue 2 (2013)

(C) Indiana University Maurer School of Law 
establishing a framework for exchanges between the constitutional object and the wider world as represented by the constitutional subject. Third, constitutionalism denotes the institutionalization of a double function, in the form of a principle-based and legally fortified striving toward universal inclusion, providing a sense of direction in time through an articulated form of constitutional consciousness.

The insights developed are briefly illustrated by the case of the global Fairtrade Certification System.

\section{INTRODUCTION}

The central function of nation-state law is to uphold normative expectations. ${ }^{1}$ In contrast, transnational law is primarily oriented toward establishing frameworks of transfer and mutual adaptation. ${ }^{2}$ This function is, however, not only unfolded within interstate frameworks. Instead of transnational law, a broader category of law, which deals with transfers and adaptations between normative orders as such, has emerged. This type of law can also be understood as a specific form of transnormative law insofar as it is characterized by a relative structural supremacy of cognitive rather than normative structures of expectations due to its primary orientation toward the establishment of increased mutual adaptability among normative orders.

Existing perspectives tend to understand the relationship between the cognitive and normative dimensions of law on the basis of a zero-sum perspective, where more of one implies less of the other. The distinction between the cognitive and normative dimensions of law is, however, logically conditioned by the continued relevance of both dimensions. From a sociological perspective, the relation between the cognitive and normative dimensions of law are moreover characterized by a relationship of mutual increase where more of one implies more of the other. Instead of experiencing marginalization, normative-based legal communication has undergone a reconfiguration, which increasingly transforms the normative dimension into a strategic rather than tactical component. This, again, is the central reason for the emergence of constitutional semantics beyond the state in recent

1. Niklas LuhmanN, Das ReCht DER Geseldschaft [LAW as a SOCIAL SySTEM] 124 (Suhrkamp Verlag 1993) (Ger.) (discussing law as a social system).

2. See generally Marc Amstutz \& Vaios Karavas, Weltrecht: Ein Derridasches Monster [Global Law: Derridasches Monster], in SOZIOLOGISCHE JURISPRUDENZ: FESTSCHRIFT FÜR GÜNTHER TEUBNER ZUM 75. GEBURTSTAG 645 [SOCIOLOGICAL JURISPRUDENCE. COMmemorative Publication for GÜNTher Teubner's 75TH BirThDaY] (Gralf-Peter Callies et al. eds. 2009) (Ger.) (developing a specific theory of world law). 
decades, insofar as constitutional structures are the framework through which a second-order normative stabilization of primarily cognitive-oriented legal processes is achieved.

This development has advanced the most in relation to social processes characterized by a primacy of functional differentiation and a reduced reliance on stratificatory and territorial forms of differentiation as internal forms of stabilization. In such settings, three-dimensional frameworks have emerged that rely on the concepts of constitutions, constitutionalization, and constitutionalism; and which serve as legal forms of the self-reflection, prestation (Leistung), and function-producing dimensions of social processes. Constitutions are here understood as internal forms of ordering which are oriented toward the establishment of a hierarchy of norms; constitutionalization as the process through which exchanges and transfers between social entities and their environments are legally stabilized; and constitutionalism as a specific legal form through which the unity of past and future are established. The transnational framework for fair-trade labeling illustrates these insights.

\section{THE EXPANSION OF Limited STATEHOOD}

Most perspectives on constitutionalism in the global realm explicitly or implicitly depart from the assumption that a weakening of statehood can be observed and that this development is one of the primary courses for the emergence of constitutionalism beyond the state. ${ }^{3}$ This perspective, in several ways, reflects a crude and simplified understanding of statehood. From a purely numerical perspective, the number of states has continued to expand rapidly throughout the last two centuries, particularly throughout the last fifty years. Furthermore, in terms of its reach, the phenomenon of statehood has gained a global status only very recently, namely in the wake of the decolonization processes of the mid-twentieth century. ${ }^{4}$ Thus, when observed from a long-term historical perspective, an unprecedented quantitative expansion in statehood has taken place in recent history. But also,

3. See generally JAN KLABBERS, ANNE PETERS \& GeIR Ulfstein, THE CONSTITUTIONALIZATION OF INTERNATIONAL LAW (2009) (discussing and debating the specialization and fragmentation that occurs in international law).

4. Rudolf Stichweh, Dimensionen des Weltstaats im System der Weltpolitik [Dimensions of the World State within the System of World Politics], in WELTSTAAT UND

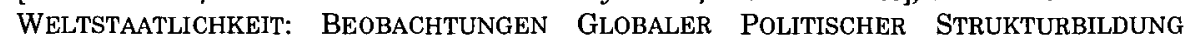
[WORLD STATE AND WORLD STATEhOOD: OBSERVATIONS OF Global Political Structural DevelopmenT] 25 (Mathias Albert \& Rudolf Stichweh eds. 2007) (Ger.) (arguing that every political communication is embedded in a system of world politics and discussing the question of whether this system constitutes a world state). 
statehood has continued expanding qualitatively. If one characterizes a "strong state" as based on a formal and operational distinction between the state and other segments of society, a fairly stable institutional setup, and an extensive though not necessarily exclusive capability to deploy political power in a generalized manner throughout its territory, then it is possible to argue that a larger part of the planet is characterized by strong statehood today than in any previous historical period. 5

But the expansion of statehood does not imply that the state-centrist society, which scholars-such as Dieter Grimm ${ }^{6}$ and Martin Loughlin ${ }^{7}$-refer to, is alive and well. A sober historical sociological perspective reveals that the state-centric society-where all social operations within a given territory are succumbed to the supremacy of the state while at the same time this state-based society remains clearly demarcated from other societies-has in fact never existed. The state, understood as a distinct political entity, has always been faced with competition from extensive forms of ordering outside the state. For example, as Chris Thornhill argued, the German state was unable to deploy its power throughout its territory in an unquestioned manner until sometime in the mid-twentieth century, after the nobility-based forms of private ordering finally collapsed in the wake of National Socialism and the Second World War. ${ }^{8}$ In a similar manner, it might be argued, the U.S. federal government did not gain unquestioned authority in the southern United States before sometime in the mid-twentieth century, because until this point federal power was continuously challenged by localistic counter movements. Furthermore, in places such as southern Italy, southeastern Turkey, and the Basque Country, similar counter movements continue to be vibrant today, just as the strong presence of localistic power structures remains the norm in most parts of Africa, Asia, and Latin America thereby creating a basis for legal pluralism. ${ }^{9}$ Thus, the vast majority of the world has not

5. See Poul F. Kjaer, The Concept of the Political in the Concept of Transnational Constitutionalism: A Sociological Perspective, in AFTER GLOBALIZATION-NEW PATTERNS OF Conflict AND Their Sociological AND Legal Reconstruction 285 (Christian Jorges \& Tommi Ralli eds., 2011), available at http://ssrn.com/abstract=1870003 (last visited Nov, 25, 2012).

6. See Dieter Grimm, The Achievement of Constitutionalism and its Prospects in a Changed World, in The Twilight of ConstiTutionalism? 3, 3.4 (Petra Dobner \& Martin Loughlin eds., 2010).

7. See Von Martin Loughlin, In Defence of Staatslehre, 48 DER STAAT 1, 1 (2009).

8. See CHRis Thornhill, A SOCIOLOgY OF CONSTITUTIONS: Constitutions AND State Legitimacy in Historical-Sociological Perspective 339 (2011).

9. For the notion of legal pluralism, see Brian Z. Tamanaha, Understanding Legal Pluralism Past to Present, Local to Global, 29 SYDNEY L. REV. (2007). 
yet been subject to a successful Hegelian codification of society in its entirety by the state. Instead, the state acts only as a thin veneer covering up very persistent private and local forms of social ordering, which operate beneath the state.

However, what is more important than this legal pluralist insight is that modern statehood has always been linked to the reproduction of a limited number of quite specific social functions. So even though a larger part of the globe is gradually characterized by a modern type of statehood, in which a limited, but generalized form of political power is deployed throughout a territorial terrain, this does not mean that all social operations within the territory in question automatically succumbed to political power. Political power remains fundamentally incapable of defining or controlling, for example, religious beliefs, the beauty of art, the value of news, or scientific truths. Political supremacy exists only in relation to the specific, albeit very fundamental, social functions of political power, such as the legitimate exercise of physical violence..$^{10}$ One consequence of this is, as Gunther Teubner observed, that even the totalitarian regimes of the twentieth century did not manage to eradicate the existence of independent sources of social meaning (Sinn) within realms, such as art, science, religion, and economy, but the regimes merely suppressed these spheres of society and forced them into an underground existence. ${ }^{11}$ Another consequence of the structural limitation inherent to modern political power is that the idea of "radical democracy" remains a fata morgana, because the kind of democratic decision-making which has emerged in nation-states is an institutional form intrinsically linked to the particularities of the medium of political power. ${ }^{12}$

\section{The MULTIPLE LAYERS OF WORLD SOCIETY}

When the diagnosis of statehood, as an expanding but nonetheless limited form of political ordering, is linked to the issue of globalization, it becomes evident that one cannot and should not see statehood and the existence of extensive forms of transnational social ordering as related to each other on the basis of a zero-sum game. On the contrary, the two dimensions of world society are engaged in a relationship of mutual increase. Whereas the globalization discourse is based on the

10. For an extensive analysis, see THORNHILL, supra note 8.

11. See GUNTHER TEUBNER, CONSTITUTIONAL Fragments: Societal CONSTITUTIONALISM AND GLOBALIZATION 21-24 (2012).

12. Poul Kjaer, Law and Order Within and Beyond National Configurations, in THE Financial Crisis in Constitutional Perspective: The Dark Side of Functional DiffERENTIATION 395 (Poul F. Kjaer, Gunther Teubner \& Alberto Febbrajo eds., 2011). 
assumption of a radical increase in the importance and centrality of transnational forms of social ordering, ${ }^{13}$ a historical perspective reveals that national and transnational forms of ordering emerged hand in hand. ${ }^{14}$ The first modern public and private international organizations appeared in the early nineteenth century at a time when only a handful of modern states, covering an extremely limited part of the global territory, existed. Thus, the radical expansion in the density of modern forms of transnational ordering over the past two hundred years unfolded hand in hand with the equally radical expansion in statehood. In both cases, the most intensive expansions further took place in the last fifty years, thereby underlining the mutually constitutiveness of the two forms of ordering even further. Thus, no inherent contradiction exists between statehood and transnational ordering. On the contrary, the two phenomena have emerged in a double movement, which implied a gradual globalization of statehood as well as a gradual replacement of the colonialist form of transnationality, characterized by a strong reliance on center/periphery differentiation, with the kind of functionally differentiated regimes that make up the central form of transnational ordering today. ${ }^{15}$ In short, national and transnational forms of ordering have kept expanding their reach in a mutually constitutive way, at the same time as the depth of their expansion remains far more limited than typically assumed due to the continued existence and vibrancy of localistic forms of social ordering, which operate "beneath" state-based and transnational sites of ordering.

It follows that the system theoretical concept of world society, which advances the idea that only one society exists and that this society mainly is characterized by horizontal relations between function systems such as politics, law, religion, economy and art, is inadequate because it does not sufficiently acknowledge the independent value of the vertical dimension of structure formation in world society as reflected in the fundamentally different organizational principles and logics characterizing local, national, and transnational forms of social ordering in the global realm. A systematic two-dimensional perspective taking both vertical and horizontal structures into account, however, implies that transnational and national structures cannot be considered functional equivalents possessing a quality that makes them mutually substitutable. ${ }^{16}$ Rather than a globalization of already existing societal regimes, which so far were embedded in national contexts,

13. See Kjaer, supra note 5 , at 285.

14. Id.

15. See Mathias Albert \& Barry Buzan, Securitization, Sectors and Functional Differentiation, 42 SECURITy DLALOGUe 413, 423 (2011).

16. Amstutz \& Karavas, supra note 2, at $652-53$. 
transnational regimes constitute a different kind of regimes that fulfill quite different societal functions. This is also reflected in their different origins. The complex constitutional conglomerates, which in everyday language are described as nation-states, grew gradually, through a metamorphosis, out of the already existing feudal orders. ${ }^{17}$ Present day transnational regimes, on the other hand, primarily emerged from within the colonial form of transnational ordering, ${ }^{18}$ through the reconfiguration of transnational processes of structure formation, away from reliance on center/periphery differentiation, and toward an increased reliance on functional differentiation as their central organizational principle.

\section{THE INTERNAL AND EXTERNAL LAW OF NORMATIVE ORDERS: CONDENSATION AND TRANSFER}

The term "transnational" is, however, problematic because it reflects the state-centered bias of our conceptual apparatus. It is a purely negatively defined term, which merely refers to a "nonstate" structure with a spatial reach extending beyond state borders. ${ }^{19}$ In praxis the term, therefore, implies that the concept of (nation) states is upheld as the central object of analysis. This has led proponents of transnational law to argue that society and not the state should be considered the central source of law creation. ${ }^{20}$ Although true in principle, the concept of society, however, remains too broad and underdetermined to serve as the principle unit of analysis. Therefore, a more adequate object of analysis is normative orders. Normative orders-such as tribes, clans, states, organizations, regimes, and networks-are located within all three layers of world society and share an ability to generate independent sources of meaning (Sinn) through the reproduction of external boundaries on the basis of inclusion/exclusion mechanisms. Internally normative orders are furthermore characterized by a striving toward establishing a coherent arrangement of rules, reflecting specific structures of expectations (Erwartungsstrukturen), ${ }^{21}$ which are linked to

17. Kjaer, supra note 5 , at 285 .

18. See generally MarTti Koskenniemi, From Apology to Utopia: THE Structure of International Legal Argument (Cambridge Univ. Press 2005) (1989) (discussing "the assumptions which control modern discourse about international law").

19. See generally Phillip C. JessuP, TRANSNATIONAL LAW (1956).

20. Peer Zumbansen, Law and Legal Pluralism: Hybridity in Transnational Governance, in REgulatory Hybridization IN THE Transnational Sphere (Paulius Jurčys, Poul F. Kjaer \& Ren Yurakami eds., 2013).

21. Robert N. Ross, Ellipsis and the Structure of Expectation, in 1 SAN JosE OCCASIONAL PAPERS IN LINGUISTICS (1975), available at http://www.eric.ed.gov/PDFS/ ED136558.pdf (requiring access to www.eric.ed.gov). 
the deployment of legal sanctions as a means of establishing compliance with these expectations. Or differently put, the condition for a social structure to become a normative order is that it gains a generalized legal form.

Rather than the far too narrow categories of national and transnational law (the latter sometimes described as international, global, or world law), it is fruitful to introduce a distinction between the internal and external dimensions of the law of normative orders. In the still maturing discourse on transnational, global, and world law, these forms of law are often considered to be functional equivalents to nation-state law in the sense that the two forms of law are considered to fulfill identical societal functions and thus to be mutually substitutable. ${ }^{22}$ The distinction between the internal and external law of normative orders, however, provide a basis for a different view. ${ }^{23}$ Indeed, both dimensions of law refer to the same internal symbol of validity (Geltungsymbol)-namely, the code law and nonlaw-which serves as the central propeller of reflexivity through which the self-preservation of law is ensured. In a similar vein, the prestation (Leistung) that the internal and external dimensions of the law of normative orders produce vis-à-vis other partial segments of world society remains the same insofar as both dimensions are oriented toward the handling of social conflicts occurring in other partial segments of society. The fundamental, and very decisive, difference between the internal and external law of normative orders can be found in relation to their respective functions vis-à-vis world society in its entirety. The primary function of the internal dimension is to ensure a positive condensation, accomplished through reiteration ${ }^{24}$ of the normative order in question, through the establishment of a general convergence of the time structures reproduced by that order (Gesamtgesellschaftlicher Zeitausgleich). ${ }^{25}$ Somewhat relativizing the Luhmannian world society thesis, this means that normative orders in their internal setup can be understood as societies insofar as "the most

22. For a critique of this perspective, see Amstutz \& Karavas, supra note 2, at 645 .

23. For more on this point see: Poul F. Kjaer: Law of the Worlds-Towards an Inter-Systemic Theory, in RECHT ZWISCHEN DOGMATIK UND THEORIE. MARC AMSTUTZ ZUM 50. Geburtstag 159 [LAW inbetween Dogmatism and Theory. For Marc Amstutz's 50TH BIRTHDAY] (Stefan Keller \& Stefan Wipraechtiger eds., 2012) (Ger.); Poul F. Kjaer, The Political Foundations of Conflicts Law, 2 Transnational LEGAL THEORY 227 (2011).

24. See Poul Kjaer, Systems in Context: On the Outcome of the Habermas/Luhmann-Debate, Sept. 2006 ANCILLA IURIS 66, 70.

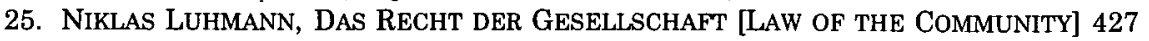
(Suhrkamp Verlag 1993) (Ger.). 
general function of a societal community is to articulate a system of norms with a collective organization that has unity and cohesiveness." 26

The function of the external law of normative orders is the direct opposite. Instead of condensation, its function is to facilitate the transfer of compressed social components (Sinnkomponente), such as economic products and capital, scientific knowledge, religious beliefs, political decisions, and educational competences, between different legally condensed normative orders. As is also apparent in Christian Joerges's conflict laws approach within the context of European Union law, 27 and Marc Amstutz's world law theory, using the private law example of Corporate Social Responsibility, ${ }^{28}$ the external law of normative orders is essentially oriented toward establishing compatibility between different legally condensed normative orders. Expressed differently, although both the internal and the external dimensions of the law of normative orders produce elements of positive and negative integration, both forms are characterized by a fundamental structural asymmetry insofar as the inner law of normative orders has a built-in bias in favor of positive integration through condensation and the external law a bias in favor of negative integration through the facilitation of transfer. ${ }^{29}$

Not surprisingly, ideologically inclined participants in the ongoing academic debate on the globalization of law and constitutional ordering tend to analyze the implications of the distinction between internal and external dimensions of normative orders as a difference between republican and liberal perspectives. ${ }^{30}$ Going beyond such indulgence in semantics, which merely scratches on the surface of the social, the fundamentally different functions of the internal and external dimensions of the law of normative orders provide an explanation of the mutual constitutiveness between national and transnational forms of ordering in world society. Increased internal condensation of a normative order implies the fortification of its boundaries through the

26. TALCOTT PaRsons, The System OF MODERn SOCIETIES 11 (1971).

27. See, e.g., Christian Joerges, Poul F. Kjaer \& Tommi Ralli, A New Type of Conflicts Law as Constitutional form in the Postnational Constellation, 2 TRANSNAT'L LEGAL THEORY 153 (2011).

28. Amstutz \& Karavas, supra note 2 , at 657.

29. For an illustration of this in relation to "Social Europe," see Christian Joerges, Rechtsstaat and Social Europe: How a Classical Tension Resurfaces in the European Integration Process, 9 COMP. SOC. 65 (2010).

30. See, e.g., Fritz W. Scharpf, Legitimacy in the Multi-level European Polity, in THE Twilight OF CoNSTitutionalism? 89 (Petra Dobner \& Martin Loughlin eds., 2010) ("develop[ing] a theoretical framework which distinguishes between the sources for legitimation in European politics ... and the exercise of public authority."). 
activation of exclusion mechanisms. ${ }^{31}$ But far more decisive is that the effective maintenance of boundaries always implies adaptation to the environment in which such boundaries are made. A central insight of systems theory is, therefore, that increased closure of a social entity is the condition for increased openness and vice versa. ${ }^{32}$ Or differentially expressed, increased condensation is conditioned by increased possibility of transfer. For example, the conversion of early modern England and the Netherlands into the first modern states was closely linked to them being comparatively open economies, just as the gradual strengthening of these states was structurally related to their embeddedness in extensive forms of private law-based transnational ordering through colonialism. ${ }^{33}$ In the same manner, the most modern states today, such as those located in North America and northwestern Europe, remain the states with the most open economics and the highest level of embeddedness in transnational frameworks, such as the quasi-imperial alliance system of the United States and the European Union. Furthermore-and rather counterintuitively-a strong correlation seems to exist between the (economic) openness of a state and the size of its public sector. The more open the economy is, the larger the public sector tends to be, because increased openness implies increased volatility, thereby creating a functional need for the introduction of stabilizing mechanisms. ${ }^{34}$

\section{The RECONFIgURATION OF COGNITIVE AND NoRMative STRUCTURES OF EXPECTATIONS}

The fundamentally different functions of the internal and external law of normative orders, as expressed in their respective orientations toward condensation and transfer, are also reflected in the structure of expectations that the two forms of law rely on. As mentioned, systems theory advances the insight that only one society-namely, world society-exists. ${ }^{35}$ Furthermore, the increasingly globalized structures of

31. Niklas Luhmann, Soziale Systeme. Grundrib Einer Allgemeinen Theorie [SOCIAL SystemS: LAYOUT Of A GENERAL TheORY] 593 (Suhrkamp, 1984) (Ger.).

32. Id.

33. See generally Martti Koskenniemi, Empire and International Law: The Real Spanish Contribution, 61 U. TORONTO L. J. 1 (2011) (discussing development of private rights from Spanish origins).

34. See generally Torben M. Andersen \& Tryggvi Thor Herbertsson, Measuring Globalization (Institute for Study of Labor (IZA), Discussion Paper 817, 2003) (Ger.) (using multifactor analysis to measure the openness of a country).

35. Niklas Luhmann, Die Weltgesellschaft, in Sozıologische Aufklärung, BAND 2: AUfSÄTZE ZUR THEORIE DER GESELLSCHAFT [SOCIOLOGICAL ENLIGHTENMENT, VOLUME 2 : ESSAYS ON THEORY OF SOCIETY] 63 (2005) (1970) (Ger.). 
world society are characterized by an increased reliance on cognitive-based structures of expectations, understood as expectations subject to revision in case of disappointment, and by a diminished reliance on normative-based structures of expectations, understood as expectations upheld in spite of disappointment. ${ }^{36}$ This dislocation is seen as linked to a relative increase in the centrality of social processes with a strong cognitive component, such as those related to science, technology, and economy, and to a concordant relative decline in the relevance of social processes with a strong normative component, such as those related to politics, morality, religion, and law in the global realm. ${ }^{37}$

This perspective, however, falls too short and goes too far at the same time. It falls too short because, as also reflected in the emergence of Managerialism ${ }^{38}$ at the transnational level, it is difficult to argue that a relative decline in the relevance of political and legal forms of communication can be observed. Rather, it is possible to observe a far more profound transformation in the very nature of such previously normative-based forms of communication. From the Open Method of Coordination, to corporate social responsibility measures and science-based risk regulation, it is possible to observe the emergence of novel forms of political and legal regulation with a strong cognitive component at the transnational level. This development is, of course, not limited to the transnational sphere, but is rather a far more profound development that also can be observed within the nation-state level of world society. ${ }^{39}$ But due to the strong reliance on functional differentiation at the transnational level of world society, rather than the kind of territorial differentiation that remains a strong feature at the nation-state level, inclusion/exclusion processes unfold in a far more dynamic manner, which leads to systemic uncertainty concerning who is included and who is excluded. Thus, a structural pressure for far more flexible frameworks and, thereby, for a move toward an increased reliance on cognitive-based frameworks can be observed within transnational structures.

In spite of the deep-seated transformation of the core fabric of law and politics through increased cognitivization, the system theoretical perspective on the relationship between cognitive and normative

36. Id. at 68 .

37. Id.

38. Marrti Koskenniemi, Miserable Comforters: International Relations as New Natural Law, 15 EUROPEAN J. OF INT’L RELATIONS 3, 395 (2009).

39. See Ino Augsberg, Observing (the) Law: The "Epistemological Turn" in Public Law and the Evolution of Global Administrative Law, 11 in REGULATORY HYBRIDIZATION IN The Transnational Sphere (Paulius Jurčys, Poul F. Kjaer \& Ren Yatsunami eds., 2013). 
expectations is nonetheless problematic. That is the case because it frames the relation as a zero-sum game. Not only is the existence of one of the two dimensions logically conditioned by the existence of the other, ${ }^{40}$ but the two sides of the distinction are mutually constitutive in the sense that they are the product of coevolutionary developments, where increased vibrancy of one dimension is conditioned by an increased vibrancy of the other dimension. Rather than a reduction in normative-based communication, a reconfiguration can be observed, which implies an increased cognitivization at the operational level-that is, at the level of tactics rather than strategy, at the level of method rather than theory, and at the level of policy rather than politics-while normative-based communication increasingly takes up a strategic role. For instance, the social phenomenon of morality-one of the prime examples of normatively based communication-has undergone a massive transformation in the wake of increased functional differentiation. It has pulled back and ceded its role as the initiator and medium of the "community terror of village life" ("Gemeinschaftsterror des dörflichen Zusammenlebens') 41 and has become a far more reflexive form of communication. In its most modern form, morality merely fulfills an alarm function, reproduced along the boundaries of social systems that are activated in two instances. ${ }^{42}$ The first instance is related to integrity preservation: When a social system sees itself as being the victim of asymmetries, crowding-out effects and colonizing tendencies emerging from its environment in the form of, for example, doping, corruption, prostitution, or pollution, that threaten the coherency of the system. In such cases, modern forms of moral communication fulfill the function of raising awareness when societal crisis emerge through processes of coalescence and boundary dissolution. ${ }^{43}$ The second instance is specific for function systems and is expansionist in nature. Within function systems, in contrast to organization and interaction systems, logics of "complete inclusion" (Vollinklusion) through a coupling of all humans with specific social roles (producing or audience roles) that correspond to the system in

40. See Moritz Renner, Death by Complexity-The Financial Crisis and the Crisis of Law in World Society, in ThE Financial Crisis IN Constitutional Perspective: The DARK SIDE OF FUNCTIONAL DIFFERENTIATION, supra note 12, at 93, 98.

41. Niklas LuhmanN, Die Gesellschaft der Gesellschaft [The Community of THE COMMUNITY] 813 (Suhrkamp 1997) (Ger.).

42. Id.

43. See generally Marc Amstutz, Eroding Boundaries: On Financial Crisis and an Evolutionary Concept of Regulatory Reform, in THE FINANCIAL CRISIS IN CONSTITUTIONAL PerspeCtive: THE DARK SIDE OF FUnCTIONAL DifFERENTIATION, supra note 12, at 223 (discussing the dynamics in the dissolution of the financial system's boundaries as well as impacts on other aspects of society). 
question can be observed. ${ }^{44}$ Missionary religions seek to convert all humans worldwide into believers, the capitalist economy seeks to transform all humans into producers and consumers, and the human rights agenda is oriented toward a formal and factual inclusion of all humans under the umbrella of human rights. But as long as such striving remains contrafactual, rather than factual, through the exclusion of a significant number of individuals, moral communication tends to emerge. ${ }^{45}$ Moral communication in this instance fulfills the function of pointing to an "untapped potential," which can be a source of further expansion of the system in question.

In a similar fashion, the retreat of politics from hands-on control over large segments of society in recent decades implies a reconfiguration of the political, rather than a diminished impact of political forms of communication. As the Foucaultians teach us, the emergence of more refined, indirect, and thus, in their abstraction, less visible ways of exercising power through new public management and through other strongly cognitivized forms of policy-making reinforces the scope for exercising power. It therefore remains impossible to claim that strongly cognitivized regulatory processes, for example, within areas as different as trade, health, food safety, or the Internet, are becoming increasingly depoliticized, since they are all bound up on the realization of internally defined normative and essentially political visions concerning the establishment of nondiscriminatory free trade, access to health, appropriate levels of food security, and access to Internet-based communication on a worldwide basis.

It follows from the above that the constitutive distinction of normative orders is the doubling of reality (Realitätsverdopplung) between facticity and normativity as expressed in the distinction between the factual existing order and the internally reproduced, and equally real, idea concerning how the order in question ought to look like. As all social phenomena are process-based, this distinction is, however, of a dynamic nature. Normative visions also change over time; they only do so at a slower pace than the actually unfolding, and increasingly cognitivized, social operations of a given order. A time gap exists between the two dimensions and bridging this gap is the central function of law in both its internal and external variants. The upholding of normative expectations through condensation, dominant at the nation-state level, as well as the increased possibility of transfer through the initiation of cognitive-based learning processes, particularly

44. RUDOLF STICHWEH, INKLUSION UND EKLUSION. STUDIEN ZUR GESELLSCHAFTSTHEORIE [INCLUSION AND EXCLUSION. STUDIES ON SOCIAL THEORY] 13 (Transcript, 2005) (Ger.).

45. Id. 
observable at the transnational level of world society, merely remain two different strategies for fulfilling this function. As we will return to in due course, establishing the unity between the two dimensions is, furthermore, the central function of constitutionalism.

\section{THE DOUBLe REFLEXIVITY OF INTERNAL CONSTITUTIONS}

Constitutions are commonly understood as frames with a quasi-transcendental character, as also expressed in the semantics of body politics in early modernity. ${ }^{46}$ If constitutions fulfilled the function of framing normative orders in their entirety, it would be possible to maintain such a perspective. That is, however, not the case since the constitutional object, throughout modern history, has been the formal organizations of normative orders rather than the normative orders themselves. This fundamental distinction has typically been disregarded within constitutional scholarship. For example, those who maintain that states are the only proper constitutional objects rely on an under-complex understanding of statehood, in which the state is equaled to a given normative order or society, in its entirety. As has been clear since Hegel's introduction of the state/society distinction, a state is, however, a specific form of formal organization among others, or more correctly, a loosely coupled conglomerate of several organizations, which exists only as long as it is formally and operationally separated from the other segments of society. ${ }^{47}$ The constitution of the state is, therefore, not the constitution of a normative order in its entirety, but of a specific organizational conglomerate.

One implication that follows from the insight that the constitutional object is not the state, but rather formal organizations, is that the range of constitutional objects is far broader than typically assumed. This is also underlined by the historical evolution of modern forms of formal organization, since the basic organizational features of states were originally developed within the framework of the Catholic Church and only subsequently adopted by the emerging modern states. ${ }^{48}$ In a similar manner, modern firms and other private organizations relied on the modern state as the role model, from which they adopted their basic

46. ERnst H. Kantorowicz, The King's Two Bodies: A Study in Mediaeval Political THEOLOGY (1957).

47. Niklas Luhmann, Die Unterscheidung von Staat und Gesellschaft, in SOZIOLOGISCHE AUFKLÄRUNG, BAND 4: BEITRÄGE ZUR FUNKTIONALEN DIFFERENZIERUNG DER Gessellschaft [SOcIOlogical ENLIGHTENMENT, Volume 4: EsSaYs ON THE FUNCTIONAL DIFFERENTIATION OF SOCIETY ] 67 (1987) (Ger.).

48. Kantorowicz, supra note 46. 
features, ${ }^{49}$ thereby opening up a conceptual horizon that makes it possible to imagine quite a radical expansion in the sort of organizations which can be observed through a constitutional lens.

A third implication is that the culturalist version of legal pluralism misses a fundamental point when leaving out the organizational perspective. Whereas the state centrist argument, concerning constitutions being specific to modern states, falls too short, its insight concerning the specific modern character of constitutions is fundamentally true, as also expressed in the intrinsic link between modern formal organizations and the emergence of constitutions. Thus, whereas modern statehood and transnational forms of ordering are coevolutionary phenomena-because they rely on the same form of modern formal organization-they are both engaged in a zero-sum relation vis-à-vis the kind of "pre-modern" and "culturalist" entities, such as tribes, clans, and nobility networks operating "beneath" both the state and transnational orders, which are gradually being marginalized as a result of the conversion of society into a modern "organizational society" (Organisationsgesellschaft).

In the wake of Hegel ${ }^{50}$ and Weber, ${ }^{51}$ a number of core features of organizations can be pinned out:

First: Formalized exclusion and inclusion mechanisms on the basis of membership enabling the establishment of boundaries between an organization and its environment. Such membership is further divided between primary (Leistungsrollen) and secondary roles (Publikumsrollen).

Second: Formalized competences and procedures of decision-making enabling a continued production of decisions, which apply to all members, with one decision recursively emerging from earlier decisions.

Third: A reliance on dual organizational and legal hierarchies as the form through which decisions are taken and transposed to the members.

Fourth: The existence of a formalized locus of authority that acts as a vehicle for producing acceptance of the decisions produced.

49. See generally Poul F. Kjaer, Post-Hegelian Networks: Comments on the Chapter by Simon Deakin, in NeTwORKS: LEGAL ISSUES OF MULTILATERAL Co-OPERATION 75 (Marc Amstutz \& Gunther Teubner eds., 2009) (using the metaphor of a guild to examine emerging structures in "the so-called network society").

50. Georg W. F. Hegel, Grundlinien der Philosophie des Rechts. Oder Naturrecht und Staatswissenschaft im Grundrisse [Base Lines of the Philosophy of Law. Or Natural Law and Political Science in Outline], in WERKE IN 20 BÄNDEN MIT REGISTERBAND, BAND 7 [WoRkS IN 20 VOLUMES WITH INDEX VolUME, VolUME 7] § 277 (Suhrkamp, 1986) (1821) (Ger.).

51. Max Weber, Bureaucracy, in From MAX WeBER: ESSAYS IN SOCIOLOGY 196 (H. H. Gerth \& C. Wright Mills eds. \& trans., 1991) (1946). 
To the extent that all of these features are in place, it becomes possible to speak of organizations as specific forms of autonomous ordering in the sense that they become self-contained structures producing decisions in a recursive manner, where one decision refers to earlier decisions through reference to an internal source of authority. As such, organizations first exist in a mature form when they become self-reflexive in the sense that the production of decisions becomes an internal process that unfolds over time.

A linkage to an external dimension, however, remains a condition insofar as it is possible to speak of organizations as formal organizations only if they are legally structured. Organizations only become formal organizations through a linkage with a legal framework because concordance with a coherent legal framework is the form through which the four dimensions mentioned above are structurally linked and coherency is established. As Teubner argued, formal organization implies a specific form of double reflexivity in the sense that the perspective of the organization in question and a legal perspective are coupled together. ${ }^{52}$ Thus, the social process reproduced by a given organization is simultaneously being mirrored in a concordant legal perspective. Or differently expressed, organizational hierarchy is mirrored in a correspondent hierarchy of legal norms.

The structural condition for the emergence of double reflexivity is, however, as indicated under point three and four above, the internal existence of hierarchy and autonomous sources of authority that can serve as a basis for collectively binding decision-making. Thus, without the existence of a political infrastructure within a given social structure, there is no basis for a stable institutionalization of double reflexivity. The Court of Arbitration for Sport can only engage in a mode of double reflexivity as long as a political counterpart exists in the form of the International Olympic Committee. Likewise, the World Trade Organization (WTO) Panel and Appellate Bodies can only establish links possessing the quality of double reflexivity through a linkage to the political dimension of the WTO in the form of the Ministerial Conference, the General Council, and so forth. This form of double reflexivity can, as done by Moritz Renner, be understood as a triangular structural coupling between the legal and political systems and given focal social process. ${ }^{53}$ This perspective implies a welcome break with system theoretical orthodoxy, since systems theory in its present form

52. Gunther Teubner, A Constitutional Moment? The Logics of 'Hitting the Bottom', in The Financial Crisis in Constitutional Perspective: The Dark Side of Functional DIFFERENTIATION, supra note 12 , at $3,25$.

53. See Moritz Renner, Occupy the System! Societal Constitutionalism and Transnational Corporate Accounting, 20 IND J. GLOBAL LEGAL STUD. 941 (2013). 
can operate only with binary relations. A break with the binary perspective not only implies a substantially different societal diagnosis than the one presented by orthodox systems theory, but also implies that one has to pursue a radical remodulation of the theory in its entirety. An alternative to the triangular perspective emerges through the distinction between primary and secondary forms of the political system. ${ }^{54}$ The distinction is between, on the one hand, couplings of law and processes that are primarily political, such as those unfolding within states and public transnational bodies such as the European Union, the United Nations, and the World Trade Organization, and, on the other hand, couplings between the legal system and private social processes where political decision-making structures have emerged internally. ${ }^{55}$ The latter form can be observed within private entities, such as trade associations, private regulatory bodies, and NGOs, and can be described as a form of "secondary politics." Secondary politics describe such structures primarily because they consider themselves related to the substantial function they exercise-for example, economy, sports, health, or religion-at the same time as their striving toward a stabilization of such processes gives them an additional political dimension.

In sum, constitutions can be understood as institutions which, in their political function, frame the body of rules and norms that establish the formal structure, decisional competences, and a hierarchically based locus of authority within an organizational structure; at the same time, they, in their legal function, lay down principles for the structuring of conflicts between norms within such an entity. Constitutions are in this sense laying down the enabling and the limitative rules guiding formal organizations. Thus, it is, in principle, possible to claim that constitutions exist in all cases where both a legal and a nonlegal social structure are bound together within the framework of a formal organization, thereby establishing a particular form of double self-constitution that ensures concordance between a legal and nonlegal perspective. Not just states, but in principle all formal organizations, including those operating in the transnational sphere, can be the object of a constitution. ${ }^{56}$

54. See TEUBNER, supra note 11 , at 114.

55. For more on this point see Kjaer, supra note 12 , at $395,425$.

56. See Hauke Brunkhorst, Constitutionalism and Democracy in the World Society, in The TWILIGHT OF ConstiTUtionAlism?, supra note 6, at 179, 197. 


\section{The Double Prestation of External Constitutionalization}

In the above section, constitutions are treated as an internal feature of formal organizations, in the sense that a linkage with law enables a condensation of authority through the establishment of legal and organizational hierarchy. But like all other types of social systems, organizations only come into existence through a demarcation and maintenance of boundaries to their respective social environments. ${ }^{57}$ The establishment of coherency through the development of a consistent set of internal norms is conditioned by the maintenance of such boundaries. At the same time organizations, like all other types of social systems, intersect with other social structures in their social environment. Besides handling the functional need of internal preservation of coherency, as outlined in the previous section, the establishment of external connectability is the most central function of constitutions. Constitutions, in their external dimension, delineate the segment of their social environments that organizations, or conglomerates of organizations, take account of. Constitutions establish "internal environments" in the sense that they internally construct an abstract medium that fulfills a dual role: First, the transposition of compressed social components, such as political decisions, economic capital and products, scientific knowledge, and religious promises of salvation that a given organization produces into the wider society. Second, the channeling and incorporation of compressed social components produced elsewhere in society into a given organization. The praxis of fulfilling this dual function is what is being described with the term constitutionalization, 58 insofar as this term denotes the process of stabilizing the exchanges between a given formal organization and the rest of society. Thus, returning to classical constitutional vocabulary, constitutionalization can also be understood as the internal process through which a formal organization delineates a constitutional subject. ${ }^{59}$ A subject that not only provides a mirror image of the organization's social environment, but also serves as the medium for the transposition of compressed social components to and from the social environment of a given organization.

57. NikLas Luhmann, Die Gesellschaft der Gesellschaft [The Community of THE COMMUNITY] 826 (Suhrkamp 1997) (Ger.).

58. See Martin Loughlin, What is Constitutionalisation?, in THE TWLIGHT OF CONSTITUTIONALISM?, supra note 6 , at 47,60 .

59. For this perspective, see also Christopher Thornhill, A Sociology of Constituent Power: The Political Code of Transnational Societal Constitutions, 20 IND. J. GLOBAL LEGAL STUD. 551 (2013). 
The classical example of such an internal environment is the legally constructed "nation" or "people" emerging within the political system in the state form. The construction of a nation-understood as an abstract and generalized form, as opposed to the sum of individuals within a given territory-is made to delineate the segment of its social environment of which a given political system observes and takes account in its decision-making. For example, the United States Congress is only obliged to account of the effects that its decision-making has on the American nation, but not the effects on the Canadian or the Mexican nations. More concretely, the concept of the nation serves as a medium through which decisions are transposed into the wider society. On the other hand, the nation is also a form through which perspectives emerging from the environment are transferred into the political system. In order for this to happen, an operationalization of the nation, through the construction of social roles and specific structures of expectation, is necessary. This takes two different forms: First, an operationalization occurs through a stabilization and formalization of relations to other organizational structures since relations are formalized through institutionalized negotiation systems (Verhandlungssysteme) in the form of advisory councils, networks, commissions, and other platforms of transfer that are established between the political system and various organizations (e.g. economic, scientific, and religious organizations). Second, operationalization occurs through the establishment of primary and secondary roles by introducing a distinction between those who govern and those who are being governed (Regierende und Regierte) ${ }^{60}$-that is, those who are internally located in the political system and those who are located in the internal environment. In democratic states, a further distinction between the citizens and the voter is further introduced within the environment. The former is serving a passive role as "audience" and the latter an active role in the sense that, through voting, the actual transfer from the environment to the political system takes place.

At the transnational level of world society, the turn to network-based governance fulfills a similar role for organizations operating within functionally delineated normative orders. In the case of the EU, governance structures such as Comitology and the Open Method of Coordination and (Regulatory) Agencies fulfill the role as heterarchcial frameworks through which transfer of compressed social components between the EU legal order and its environment (including

60. Niklas Luhmann, Die Zukunft der Demokratie, in SozIOLOGISCHE AUFKLÄRUNG, BAND 4: BEITRÄGE ZUR FUNKTIONALEN DIFFERENZIERUNG DER GESSELlSCHAFT [SOCIOlOGiCAl ENLightenment, Volume 4: ESSAYS ON THE FUnCTIONAL DIFFERENTIATION OF SOICETY] supra note 47, at 126. 
the legal orders of the Member States) are framed. ${ }^{61}$ Comparable, though far more embryonic, structures have also emerged around global public and private organizations such as large-scale NGOs, multinational companies, the International Monetary Fund (IMF), the World Bank, and the World Health Organization (WHO). These organizations share the feature that they are faced with the challenge of delineating their respective environments but cannot turn to the concept of a nation, as they are not internally stabilized through a reference to territorial demarcations, thereby triggering the emergence of the concept of "stakeholders" as a functional equivalent to the concept of the nation. The stakeholder form is characterized by a far stronger cognitive component when compared with the form of the nation, insofar as it possesses a strong element of exchangeability on the basis of a criterion of functionality. ${ }^{62}$ Although nations rarely have been the stable units that nationalist theory and most normative political and legal theories assume them to be, the logics of inclusion and exclusion nevertheless have a far stronger temporal character within stakeholder settings. ${ }^{63}$

The increased level of temporality, and thus contingency, is the likely explanation of the strong reliance on rights within transnational settings. Rights are the legal form which constitutionalization takes. Whereas Thornhill seems to reduce rights to the only form through which inclusion/exclusion processes are handled, 64 the structural capability of both national and transnational formal organizations to develop rights regimes seems to be conditioned by their attachment to generalized nonlegal mediums that represent a distilled version of existing sociocultural material, as expressed in the nation and stakeholder phenomena. Even though rights regimes tend to emerge from within the social processes they are attached to-rather than being externally imposed-they become identifiable and operational only when a distinction between the legal and the nonlegal dimensions is established, leading to the emergence of a specific form of double prestation. Traditionally, the register of rights is understood as the framework through which, in the same operation, liberties are secured and obligations imposed on legal subjects. ${ }^{65}$ The central societal

61. Poul F. KJAER, BetweEn Governing AND GovernanCE: ON THE EMERGenCe, FUNCTION AND FORM OF EUROPE'S POST-NATIONAL CONSTELLATION 37 (2010).

62. See Poul F. Kjaer, The Metamorphosis of the Functional Synthesis: A Continental European Perspective on Governance, Law and the Political in the Transnational Space, 57 WIS. L. REV. 489 (2010).

63. Id.

64. Thornhill, supra note 59 .

65. Id. 
prestation (Leistung) of rights is, however, to provide compressed social components with a legal form, which enable their transfer in a manner that does not destabilize the operational integrity of the donating as well as the receiving entity. ${ }^{66}$

It follows that constitutionalization does not only imply an increase in the self-reflexivity of a given formal organization. Constitutionalization is not just an exercise in negative self-binding that organizations pursue to reduce the risk of self-destruction through systemic overstretch. ${ }^{67}$ This view, which can be traced back to Luhmann's strategic, but essentially contingent, choice to emphasize the self-reflexivity of social systems while systematically playing down the prestation and function dimensions of social systems, leads to an empirically implausible description of society.68 Rather, constitutionalization processes provide a far more positive contribution toward other segments of society insofar as they are aimed at reducing negative externalities, colonizing tendencies, and crowding out effects vis-à-vis the respective environments of constitutional orders. This is also confirmed by the contextual settings within which constitutions emerge. Constitutions never stand alone, but always emerge in coevolutionary settings where several orders emerge simultaneously. Nation-states, for example, are not unitary structures but rather take the form of constitutional conglomerates where state constitutions, church constitutions, and labor constitutions come together. This again makes the multiple intersections between constitutions into battlefields where constitutional orders are delineated and where justifying narratives emerge concerning the prestation that specific constitutional orders produce vis-à-vis other segments of society. The emergence of constitutions is structurally conditioned by constitutionalization processes capable of guaranteeing that mutually reinforcing coevolutionary processes unfold. The emergence of an autonomous constitutional order within the European Union is a perfect example of this, insofar as the internal establishment of legal and organizational hierarchy was conditioned on the coevolutionary emergence of heterarchical legal and organizational frameworks, in the form of the governance structures, such as Agencies, Comitology, and the Open Method of Coordination, which ensured concordance between the EU constitutional order and its environment, most notably the Member State legal orders.

66. Id.

67. See Teubner, supra note 52 , at 21 .

68. Luhmann maintains formal equality between the three dimensions at the same time as his empirical descriptions of social processes tend to have a one-sided focus on the reflexivity dimension. For the formal layout, see LUHMANN, supra note 25, at 610 . 


\section{The Double Function of Constitutionalism Between PAST AND} FUTURE

The distinction between internal ordering and external heterarchy, as expressed in the distinction between constitutions and constitutionalization, constitutes a paradoxical tension. This tension can also be described utilizing the distinction between hierarchically organized and spontaneous heterarchical processes. ${ }^{69}$ A normative order first exists when a unity of these two dimensions is established, and establishing this unity necessitates recourse in time. In the same manner, as normative constitutional theory seeks to dissolve the tension between republican politics and liberal rights through societal learning processes unfolded over time, ${ }^{70}$ it is also possible to observe from a sociological perspective that constitutional setups do not just mirror existing structures, but rather, express a specific vision of the future on the basis of a specific understanding of the past. ${ }^{71}$ Such visions can also be described as representing a form of "constitutional consciousness" capable of providing a basis for a counterfactual claim concerning a possible constitutional framing of a normative order in its entirety. It is the establishment of such constitutional consciousness that is described with the term constitutionalism.

As indicated earlier, law operates with counterfactual propositions, which are oriented toward the future. Constitutionalism, however, implies orientation toward a specific kind of counterfactual proposition that can be described with the term double function. Constitutionalism implies that from a focal perspective-including economic, political, or environmental-as well as from a legal perspective, a vision of "complete inclusion" is developed, which implies that, in principle, all humans can be subject to inclusion into the normative order in question. Originally developed within the Church of Rome, the counterfactual striving for complete inclusion-in this case through the transformation of all individuals into members of the Catholic Church and the subordination of all worldly powers into subordinates of Rome-has become generalized. For example, the French Republic, the historical role model for most continental states, has traditionally relied on a self-understanding that is closely linked to the counterfactual idea concerning a realization of the ideals of the French revolution throughout the world. Similar developments can be observed within sectorial regimes consisting of constitutional organizations and their

69. See TEUBNER, supra note 11 , at 89.90 .

70. See Jürgen Habermas \& William Rehg, Constitutional Democracy: A Paradoxical Union of Contradictory Principles?, 29 POL. THEORY 766, 774 (William Rehg trans., 2001).

71. Id. 
surrounding constitutionalized networks, such as the WTO regime, the Internet Corporation for Assigned Names and Numbers (ICANN) regime, the WHO regime, and the still emerging global human rights regime. ${ }^{72}$ Counterfactual objectives are universal in nature, such as the striving toward the realization of nondiscriminatory free trade, free and uncensored global access to the Internet, basic worldwide access to health, and not only a formal, but also a de facto inclusion of all humans under the umbrella of the human rights regime. In other words, constitutionalism implies the institutionalization of normative teleology's and a hierarchical relationship between teleology's and increasingly cognitivized processes of juridification. Once such logics are in place, it is possible to talk about constitutionalism in a deep and mature sense. Constitutional ordering is, therefore, not only about facilitative and limitative rules, but also reflects a move toward self-transcendence through the unfolding of a universalistic aspiration.

\section{The EXAmple of the FaIRTRADE Certification System}

From the theoretical framework outlined above, three core dimensions of a mature constitutionalist order can be deduced:

A constitutional order characterized by double reflexivity through a coupling between a constitutional object, in the form of a hierarchical organization that can produce an autonomous source of authority, and a concordant legal framework.

Constitutionalization through double prestation, implying a coupling between, on the one hand, an internal reconstruction of an external constitutional subject within the constitutional object, and, on the other hand, a register of legal rights, establishing a framework for exchanges between the constitutional object and the wider world, as represented by the constitutional subject.

Constitutionalism, through the institutionalization of a double function, in the form of a principle-based and legally fortified striving toward universal inclusion, providing a sense of direction in time through an articulated form of constitutional consciousness.

The real world existence of such frameworks can be briefly illustrated through the example of the Fairtrade Certification System. The scheme is organized and overseen by a private international organization, the Fairtrade Labeling Organizations International (FLO). ${ }^{73}$ FLO was founded in 1997 as an international umbrella

72. Andreas Fischer-Lescano \& Gunther Teubner, Regime-Collisions: The Vain Search for Legal Unity in the Fragmentation of Global Law, 25 MiCH. J. OF INT’L. L. 999 (2004).

73. See What We Do, FAIRTRADE INT"L, http://www.fairtrade.net/what_we_do.html (last visited Nov. 25, 2012). 
organization for national fair trade labeling organizations. Its core task is to develop internationally coordinated standards for fair trade and to assist producers in gaining and maintaining certification of fair trade. The central focus is on agricultural products, such as bananas and coffee, but FLO's reach has also been expanded into areas such as textiles. The products are, however, part of global production, distribution, and consumption chains that typically imply transfers between developing and developed parts of the global economy. ${ }^{74}$

The orientation is twofold, as the standards are aimed at ensuring ecological sustainability and establishing social and labor standards in the production process. A key strategy of FLO is to establish transparent and long-term trade relations among producers, importers, processers, and distributors through long-term contracts that set minimum prices, thereby reducing the exposure of the producers to market volatility and pressure from large-scale companies. ${ }^{75}$ In addition, a "social premium" is paid, serving as a kind of de facto tax that is allocated to the promotion of common goods relevant to the producers and is typically invested in local development, such as education and health facilities for the producers. The producers who own the production sites-typically agricultural land-are organized in cooperatives. Alternatively, work councils are established that represent employees vis-à-vis landowners. ${ }^{76}$

In 2004, the organization was split into two subunits: FLO International and FLO-CERT. Both are based in Bonn, Germany. FLO is a not-for-profit organization ("eingetragener Verein") and operates in concordance with the German public benefit law. FLO-CERT is structured as a limited-liability company $(G m b h)$ under German law. ${ }^{77}$ FLO International maintained the core task of developing fair trade standards while FLO-CERT ensures that producers and traders comply

74. For an overview of the framework see especially ALEX NICHOLLS \& CHARLOTTE OPAL, FaIR TRAdE: MARKET-DRIVEN ETHICAL Consumption (2005). See also Daniel JAFFEe, BREWING JUSTICE: FAIR Trade COFFEE, SUSTAINABILITY, AND SURVIVAL (2007) (examining if fair trade is working by looking at coffee farmers in Mexico); Valentin Beck, Theorizing Fairtrade From a Justice-Related Standpoint, 3 GLOBAL JUSTICE: THEORY, PRACTICE, RHETORIC 1 (2010) (examining fair trade in two step process, first looking at interactions of participants and then looking at responsibilities of participants); Loraine Ronchi, The Impact of Fair Trade on Producers and Their Organisations: A Case Study with Coocafé in Costa Rica (Poverty Research Unit at Sussex, Prus Working Paper No. 11, 2002), available at http://www.sussex.ac.uk/Units/PRU/wps/wp11.pdf.

75. What we do, supra note 73 .

76. Id.

77. Fairtrade Labelling Organizations International, Constitution of the Association, $\S \S$ 1.1-1.2 (amended June 10, 2011), available at http://www.fairtrade.net/fileadmin/user_ upload/content/2009/about_us/documents/flo-constitution-june-2011-english.pdf. 
with the standards of FLO International. ${ }^{78}$ FLO-CERT has the competence to impose sanctions in case of noncompliance. The ultimate sanction is decertification and exclusion from the system.

FLO has developed a foundational text that it calls a constitution. ${ }^{79}$ The constitutional text is an eleven-page document with a preamble and eighteen paragraphs that set out the basic framework on which the organization operates, including a specification of its central organs and the purpose of its activities. The constitutions can be amended only through a majority of 75 percent of the organization's members. ${ }^{80}$ The constitution establishes the General Assembly as the central institutional organ. ${ }^{81}$ It is comprised of 50 percent producer representatives and 50 percent representatives from the national labeling organizations. ${ }^{82}$ The two groups are further organized in two different subassemblies. The General Assembly has the characteristics of a "parliament" insofar as its core function is representation, the development of legislative-like rules, and general oversight. ${ }^{83}$ As such, the assembly serves as the ultimate locus of authority for the organization while remaining coupled to law through the constitution, the internal procedural framework, and through the reliance on German law.

The General Assembly elects the board that consists of five representatives from labeling organizations; four representatives from producer organizations (representing different geographical regions); two representatives from certified traders; and three external independent experts. ${ }^{84}$ Both in relation to the assembly and the board, a key characteristic is the deliberate design of a multiple-stakeholder framework. The organization is, in this sense, mimicking a balance-of-interest approach as known from classical state-based constitutional set-ups. At the same time, the "external experts" are granted a privileged position as they hold the key to establishing a majority. The mediation between different stakeholder groups is assigned to representatives who are expected to represent a neutral and knowledge-based, and thus "cognitivized," position. A similar framework exists in relation to the various subcommittees, most notably the standard setting committee.

78. Certifying Fairtrade, FAIRTRADE INTERNATIONAL, http://www.fairtrade.net/ certifying_fairtrade.html? $\& \mathrm{~L}=0$ (last visited June 12,2013 ).

79. Id.

80. Id. at $\S 3.1$.

81. Id. at $\S 7$.

82. Id. at $\S 9,10$.

83. Id. at $\S 7.1$.

84. Id. at $\S 12$. 
The multiple-stakeholder framework also serves as an internal mirror reflecting the organization's external environment. By defining specific categories of producers, importers, processers, and distributors in its constitution, ${ }^{85}$ FLO delineates the segment of world society that can be potentially included in the framework, and thereby the boundaries of the normative order it seeks to establish. This delineation is then combined with specific procedures for actual inclusion through membership application and certification, thereby creating a dual framework based on a distinction between potentiality and actuality. Actual inclusion is, furthermore, linked to a dense framework of rights, imposing a dual framework of obligations and standing, most notably through adherence to standards and through access to review and decision-making processes. At the same time, the rights framework serves as the central infrastructure, which enables the production of a specific prestation vis-à-vis other segments of world society, insofar as it is oriented toward the facilitation of transfer of products and capital between the producers, importers, processers, and distributors. Thus, a move toward constitutionalization can be observed as FLO defines a constitutional subject via its multiple-stakeholder framework and subsequently seeks to minimize the distinction between potential and actual inclusion. The implementation of the rights dimension is outsourced to FLO-CERT, which certifies compliance through inspections and imposes sanctions in case of noncompliance, such as demands for corrective measures and, ultimately, expulsion. Thus, FLO-CERT serves as an independent "judiciary" that combines an investigative function with the objective of applying the norms produced by FLO.

Finally, FLO has condensed its activities in a mission-namely, "to connect disadvantaged producers and consumers, promote fairer trading conditions and empower producers to combat poverty, strengthen their position and take more control over their lives." 86 This mission is deduced from a vision. The vision of FLO "is a world in which all producers can enjoy secure and sustainable livelihoods, fulfill their potential and decide on their future." 87 The organization remains strategically guided by a normative, and thus counterfactual, objective concerning full inclusion for the segment of world society, which it orients itself against, thereby externalizing the tension between potential and actual members in the future. Thus, FLO can be understood as a fully-fledged normative order, which internally

85. Id.

86. Our Vision, FAIRTRADE INT'L, http://www.fairtrade.net/our_vision.html (last visited Oct. 28, 2012).

87. Id. (emphasis added). 
produces coherency between its different dimensions, as represented by producers, importers, processers, and distributors. And so, FLO externally demarcates itself through the double delineation of potential and actual members, as well as through the establishment of a constitutional structure characterized by a dual political and legal hierarchy and a normative vision that grants it an articulated form of constitutional consciousness that points to the future. 
